\title{
LEGAL PROTECTION OF MIGRANT WORKERS AGAINST THREATS OF ABUSE DISCRIMINATION IN A DIPLOMATIC RELATIONSHIP PERSPECTIVE BETWEEN COUNTRIES
}

\author{
Yapiter Marpi \\ Faculty of Law, Universitas Jakarta, Indonesia, \\ E-mail: yapitermarpi@gmail.com
}

Submitted: June 29, 2021; Reviewed: July 7, 2021; Accepted: September 2, 2021

\begin{tabular}{l}
\hline \multicolumn{1}{c}{ Article Info } \\
\hline Keywords: \\
Protection of Laws, Labor, Migrants, \\
Diplomacy.
\end{tabular}

\section{DOI:}

10.25041/lajil.v3i2.2366

\begin{abstract}
Manpower is the driving force of an activity that can determine the implementation of manpower through the available manpower, which is an integral part of national development based on Pancasila and the 1945 Constitution of the Republic of Indonesia. Problems that occur to Indonesian migrant workers abroad occur cases, abuse and discrimination occur, such as cases of sexual harassment, cases involving convictions of migrant workers, cases of unpaid wages, to cases of unilateral termination of employment. This research uses normative juridical research methods and is legally supported by socio descriptive analysis employing primary, secondary, and tertiary data. The purpose of this research is that the placement of Indonesian workers abroad is one of the State's efforts to realize the same rights and obligations for workers to improve their standard of living. The study results show that the protection of migrant workers needs to be affirmed with certainty against the regulation of Law Number 18 of 2017. The aim is to guarantee Indonesian Migrant Workers and their families in realizing guaranteed fulfillment of their rights in all activities before working, during work, and after working in legal, economic aspects, and social. The role of state diplomacy is needed in protecting and fulfilling the rights of migrant workers because this condition involves relations between countries, as people who have no choice of provider for life, workers. Therefore the role of the State must be very spearheading in providing legal protection to migrant workers because their status is minimal. The research analysis results to realize the implementation of international and national legal instruments from Indonesia need to be optimized through diplomacy from those with interest so that protection is said to be effective and optimal.
\end{abstract}




\section{A. Introduction}

Through the Government of President Ir. Joko widodo, in 2020, the Government is preparing a Draft Job Creation Law using the Omnibus Law method. The placement of Indonesian workers abroad is one of the Government's efforts to realize the same rights and obligations for workers to improve their standard of living. With this migration, Indonesian workers are also able to contribute to the Indonesian economy. As mandated by Article 27 paragraph (2) of the 1945 Constitution of the Republic of Indonesia, it is stated that "Every citizen has the right to work and a decent living for humanity". Based on the Article, the Government is obliged to provide employment opportunities for its people to live appropriately following the limits of humanity. Humans are living beings who were born to develop physically and psychologically.

Therefore, the law, which has a regulatory nature, must be developed according to people's lifestyles. It should be noted that the number of migrant workers is increasing along with the number of workers. Three key factors influence the increase in the phenomenon of labor migration. The first is the Pull Factor caused by changes in demographics and labor needs by industrialized countries. The second is the Push Factor, related to population issues, unemployment, and crisis pressures. Unemployment in Indonesia continues to increase and has reached seven million people, which is one of the factors that pushed the Omnibus Law on Job Creation to be ratified. The Job Creation Law Number 11 of 2020 is also to improve the quality of Indonesian workers. As people who do not choose livelihood, migrant workers are forced to work for other people. ${ }^{1}$

The position of the employer determines the rules and employment agreements. Therefore, the role of the Government is essential to provide legal protection to migrant workers because their status is minimal. From the existing statement, the State should protect its citizens, including Indonesian migrant workers who live and work outside the territory of the Republic of Indonesia. The workers may obtain protection from the State through its organs such as the Embassy of the Republic of Indonesia, the Consulate General of the Republic of Indonesia, an institution diplomatic and consular representatives owned by Indonesia Commitments to protect Indonesian migrant workers carried out optimally. Such protection focuses on the balance of Indonesian migrant workers' rights and obligations. Protection of migrant workers must also not distinguish the status and background of migrant workers. ${ }^{2}$

When the global COVID-19 crisis halted international labor migration, ${ }^{3}$ there was a decrease in the number of workers in the short, medium, and long term, including a crisis against women workers. Women who migrate may face double discrimination in the workplace. Discrimination involves navigating their roles as immigrants while also dealing with gender inequality. ${ }^{4}$ Recently, the International Labor Organization (ILO) released a study on female workers in the garment industry sector in the Asia Pacific region. With the theme "The gender impact of Covid-19 in the garment sector". ILO data reports that the Corona pandemic has increasingly led to discriminatory practices and harassment against women, including injustice in the issue of wage rights in garment industry companies. The

\footnotetext{
${ }^{1}$ H.N. Rosalina and L. T. Setyawanta, "Perlindungan Hukum Terhadap Pekerja Migran Sektor Informal Dalam Perspektif Teori Bekerjanya Hukum Di Masyarakat," Jurnal Pembangunan Hukum Indonesia 2, no. 2 (2020): 174-87, https://doi.org/10.14710/jphi.v2i2.174-187.

2 Ida Hanifah, "Peluang Tenaga Kerja Asing Untuk Bekerja Di Indonesia Berdasarkan Rancangan UndangUndang Cipta Kerja," De Lega Lata: Jurnal Ilmu Hukumm 6, no. 1 (2020): 158-73, https://doi.org/10.30596/delegalata.v6i1.5536.

${ }^{3}$ Andreas Neef, "Legal and Social Protection for Migrant Farm Workers: Lessons from COVID-19," Agriculture and Human Values 37 (2020): 641, https://doi.org/10.1007/s10460-020-10086-w.

${ }^{4}$ Sally C. Moyce and Marc Schenker, "Migrant Workers and Their Occupational Health and Safety," Annual Review of Public Health 39, no. 1 (2017): 13-17, https://doi.org/10.1146/annurev-publhealth-040617-013714.
} 
ILO explained that the garment industry is the company that absorbs the most labor from women. Therefore, the International Labor Organization (ILO) made a series of recommendations to solve this problem, including a more equitable gender equality agenda or as much as 80 percent. However, when the world experienced the Covid-19 pandemic, these female workers experienced new problems.

The problem is not far from the impact of the Covid-19 pandemic. Because of the challenges they face at work and expectations regarding women's obligations at home, the condition is that imports from major buying countries from garment exporting countries in Asia are experiencing a decline of up to 70 percent in the first half of 2020. Thus, many garment companies have gone out of business, and inevitably many female workers have become victims of Termination of Employment (PHK). ${ }^{5}$ The protection of Indonesian migrant workers abroad as Indonesian citizens is also based on Law Number 37 of 1999 concerning Foreign Relations. Article 19 regulates "providing protection and legal assistance for Indonesian citizens and legal entities abroad, under national laws and regulations as well as international law and practice." 6

A common thread has been drawn from the description above on the lack of harmony between international legal instruments and national law for migrant workers' protection. However, there are still gaps in the field regarding implementing legal instruments for labor absorption barriers in Indonesia, namely the lack of an educated workforce, poor infrastructure, and an empirically convoluted policy framework. The facts on the ground are very different from the original purpose of making legal instruments related to the protection of migrant workers. The implementation of Indonesia's international and national legal instruments needs to be optimized through diplomacy from interested parties so that protection is effective and optimal.

\section{B. Discussion}

\section{Optimizing the Protection of Migrant Workers}

According to the International Labour Organization (ILO), there is 244 million migrants worldwide. ${ }^{7}$ Rapid economic growth in some Asian countries, combined with high labor demand and wages, as well as a lack of employment with the low wages in the country of origin, have been the two pull and push factors in Indonesian labor migration. ${ }^{8}$ Indonesia is a country that sends the largest workforce of its citizens to work abroad either at the request of the country concerned or the active initiative of implementing placements working abroad. Following the role and position of the workforce, it is necessary to develop manpower to improve the quality of the workforce and their participation in development. It is also necessary to have reliable and professional quality human resources. Moreover, it increases workers' and their families' protection following human dignity. It is in line with these objectives in the era of globalization and increasing development in all sectors of life. ${ }^{9}$

\footnotetext{
${ }^{5}$ KSBSI, "Dilema Diskriminasi Buruh Perempuan Industri Garmen Ditengah Pandemi," www.ksbsi.org, 2020, https://www.ksbsi.org/home/read/1327/Dilema-Diskriminasi-Buruh-Perempuan-Industri-Garmen-DitengahPandemi.

${ }^{6}$ Yapiter Marpi, “The Criticism of Social Justice in Economic Gap,” Insignia: Journal of International Relations 2 (2021): 23-31.

7 David Koh, "Migrant Workers and COVID-19," Occupational \& Environmental Medicine 77, no. 9 (2020): 634, https://doi.org/10.1136/oemed-2020-106626.

8 Henny Nuraeny, "Trafficking of Migrant Workers in Indonesia: A Legal Enforcement and Economic Perspective of Prevention and Protection Efforts," European Research Studies Journal 20, no. 4B (2017): 17, https://doi.org/10.35808/ersj/871.

${ }^{9}$ Maulida Indriani, "Peran Tenaga Kerja Indonesia Dalam Pembangunan Ekonomi Nasional," Gema Keadilan 3, no. 1 (2016): 74-85, https://doi.org/10.3592/2.
} 
The Covid-19 pandemic has caused multidimensional shocks, such as education, health, economy, and labor. The law should exist to protect workers amid the problems caused by the current pandemic. As regulated in Article 27 paragraph (2) of the 1945 Constitution of the Republic of Indonesia, that the existence of legal protection for workers aims to be able to guarantee equality in obtaining opportunities and freedom from discriminatory treatment, including freedom from different treatment based on the religion they adhere to is a right - a person's fundamental rights. The Government should pay attention by negating regulations regarding the use of foreign workers in Indonesia. These regulations are not regulated separately but are part of the compilation of Law Number 13 of 2003 concerning Manpower, contained in chapter VIII articles 42 to 49. Furthermore, it regulates that employing foreign workers must have written permission, plans for the use of foreign workers, types of positions and competency standards for foreign workers, the appointment of Indonesian citizens as companions for foreign workers, education and training for Indonesian workers, as well as the obligation of employers to repatriate workers foreigner after the employment relationship ends. This labor regulation is strengthened by Presidential Regulation No. 20 of 2018 concerning the use of foreign workers.

The view of international law, for example in Article 2 of the Universal Declaration of Human Rights (UDHR) which states: "Everyone is entitled to all the rights and freedoms outlined in this Declaration, without distinction of any kind, such as race, color, sex, language, religion, political or another opinion, national or social origin, property, birth or another status". This means that everyone has the same right to be free from discriminatory treatment, including based on one's religion. ${ }^{10}$

The regulation states that workers who come to Indonesia occupy certain positions, thus do not allow any unskilled workers because the law clearly states that there must be a transfer of technology and expertise from foreign workers to Indonesian workers. However, there are still violations of licensing regulations and the use of foreign workers. Regarding the protection of migrant workers, the United Nations (UN) has issued a convention, namely the International Convention on the Protection of The Right of All Migrant Workers and Members of Their Families 1990 concerning the International Convention on the Protection of All Immigrant Workers and Members of Their Families. In the Convention, it is seen that one of the international legal instruments protects not only migrant workers but also their family members. The opinion of CST Kansil said that legal protection is a legal effort given by law enforcement officers to legal subjects to create a safe situation from all threats and obstacles given by anyone. While according to Satjipto Rahardjo, the purpose of legal protection is to protect human rights. ${ }^{11}$

The United Nations adopted the Migrant Workers Convention in December 1990 (UN Convention on the Protection of Rights of Migrant Workers and their Family Members) on December 18, 1990. The Convention entered into force on July 1, 2003 after ratification by 20 countries reached in March 2003.

The legitimacy of the provisions of Article 1 number 14 of Law Number 13 of 2003 concerning Manpower defines a work agreement, namely an agreement between a worker/laborer and an entrepreneur or employer that contains the terms of work, rights, and obligations of the parties. The Convention to ratify the Migrant Workers Convention with Law Number 6 of 2012 in principle protects all migrant workers regardless of how they enter a country. This Convention regulates the rights that apply to all migrant workers regardless of

\footnotetext{
${ }^{10}$ Abdulkadir Muhammad, Hukum Dan Penelitian Hukum (Bandung: PT.Citra Aditya Bakti, 2014).

11 Ali Ismail Shaleh and Raihana Nasution, "Perlindungan Hukum Tenaga Kerja Migran Indonesia Di Arab Saudi Sebagai Negara Non Internasional Convention on the Protection of the Rights of All Migrant Wokers and Members of Their Families," Jurnal Yustisiabel 4, no. 1 (2020): 27-36, https://doi.org/10.32529/yustisiabel.v4i1.481.
} 
their legal status and regulates the rights that apply to migrant workers and fundamental freedoms for migrant workers. This Convention provides a complete standard of human rights that all countries must guarantee to all persons who qualify as migrant workers. This Convention is an international Convention that comprehensively regulates the relationship between the migration of people and human rights. Forty-one countries have ratified this Convention, most of which are sending countries, such as Mali, the Philippines, Sri Lanka, and Indonesia.

\section{Migrant Guarantee of Elimination of Migrant Discrimination}

International migrants include a diverse group of people, along with workers, refugees, students, undocumented immigrants, and others. ${ }^{12}$ Article 2 paragraph (1) of the Migrant Workers Convention defines a "migrant worker" as "any person who is to be engaged, is engaged or has been engaged in a remunerated activity in a State of which he or she is not a national". This means that international law protects migrant workers, namely someone who is about to, is in the middle, or has been doing paid work in a country where the person is not a local citizen. For refugees and stateless persons, their rights will only be recognized in the Convention if this is also regulated in the national provisions of the country concerned. Referring to these provisions, specific religious requirements in the labor recruitment process violate workers' rights to have a religion and be free from discrimination.

This Convention seeks to guarantee the human rights of migrant workers, broadly including civil and political, economic, and socio-cultural rights. One group called illegal immigrants are usually asylum seekers who refuse a permanent residence permit, or people (overstayer), namely people who live in a country but whose residence permit/visa has expired and is categorized as illegal immigrants. ${ }^{13}$

Migrant labor includes cleaning the house, cooking, washing and ironing clothes, caring for family members; children, elderly or sick; gardening, housekeeping, driving for the family, and even caring for household pets. However, the level of willingness of countries to ratify this Convention is relatively low. In addition, considering the structure of the International Convention, whose validity depends on the existence of ratification, the protection of migrant workers depends on the presence or absence of cooperation between governments, especially the receiving and sending countries. This intergovernmental cooperation is sometimes not carried out so that there are still human rights violations against migrant workers so that their lives are very miserable in other countries. In this context, the sending and receiving countries are responsible for protecting their nationals who become migrant workers abroad. ${ }^{14}$

Regulations regarding the implementation of the right to be free from discrimination against workers in the labor recruitment process can also be seen in other regulations besides the Manpower Law, for example, in Law Number 39 of 1999 concerning Human Rights (HAM) and Law Number 40 of 2008 concerning Elimination of Racial and Ethnic Discrimination (PDRE). In the Human Rights Law, the protection of the right to be free from discrimination by anyone has been regulated in Article 3 paragraph (2) of the Human Rights Law, which states that everyone has the right to protection of human rights without discrimination, including the right to religion. And in Article 4 of the Human Rights Law, it is

\footnotetext{
${ }^{12}$ Waleed M. Sweileh, "Global Output of Research on the Health of International Migrant Workers from 2000 to 2017," Globalization and Health 14, no. 105 (2018): 2, https://doi.org/10.1186/s12992-018-0419-9.

${ }^{13}$ Hugo and W. R. Bohning Graeme, Providing Information to Outgoing Indonesian Migrant Workers (Manila: International Labour Office, 2000).

${ }^{14}$ Koesrianti, "Perlindungan Hukum Pekerja Migran Penata Laksana Rumah Tangga (PLRT) Di Luar Negeri Oleh Negara Ditinjau Dari Konsep Tanggung Jawab Negara,” Yustisia Jurnal Hukum 4, no. 2 (2015): 245-68, https://doi.org/10.20961/yustisia.v4i2.8642.
} 
stated that the right to religion is a human right that is non-degradable. ${ }^{15}$

In addition to the Human Rights Law, what is meant by acts of racial and ethnic discrimination is regulated in Article 1 number 1 of the PDRE Law. This Article states that racial and ethnic discrimination are all forms of action that distinguish, exclude, limit, or choose based on race and ethnicity. Resulting in a reduction in equal treatment in several areas of life, one of which is in the economic field, including employment. In this case, specific religious requirements can be a form of discrimination against ethnicity because of Article 1 number 2 of the PDRE Law. Consequently, Article 1 describes ethnicity as a classification based on values, habits, beliefs, norms, customs, history, language, geographical conditions, and relationships. Classification based on belief is closely related to religion, so providing specific religious requirements in the recruitment process is a form of ethnic discrimination. Acts that include discrimination against ethnicity and race are then reaffirmed in Article 4 letter of the PDRE Law. ${ }^{16}$

Through Presidential Instruction Number 6 of 2006 concerning Policy Reform of the Placement and Protection System for Overseas Migrant Workers, stakeholders have taken various steps to improve placement and protection services for immigrants abroad: ${ }^{17}$

a) Increasing the legal basis that forms the basis for regulating the placement and protection of Indonesian Migrant Workers abroad in the form of Decree of the Minister of Manpower No. 104 A/Kepmen/1999 concerning the Placement of Immigrants Abroad into the PPTKILN Law;

b) Establishment of the National Agency for Placement and Protection of Indonesian Migrant Workers (BNP2TKI) The establishment of BNP2TKI is based on Presidential Regulation No. 81 of 2006 concerning the National Agency for the Placement and Protection of Indonesian Migrant Workers;

c) Simplification of the TKI placement service bureaucracy, such as simplifying the placement procedure from 24 nodes to 14 nodes;

d) Improving the quality of the immigrant workforce through training in skills, abilities, language, and mental preparation. Will only place TKI who are judged to have met the competency requirements as evidenced by a certificate from the Professional Certification Institute (LSP) appointed by the Ministry of Manpower and Transmigration;

e) Protecting the rights and assets of Indonesian workers through the TKI insurance program implemented by five Insurance Consortiums. In this case, the Insurance Consortium is also required to cooperate with legal aid agencies/lawyers in the country of placement of the TKI;

f) Improve bilateral relations with eight placement countries, namely Malaysia, South Korea, Jordan, Kuwait, Taiwan, Australia, and the United Arab Emirates, signing a Memorandum of Understanding (MoU). Currently, the signing of MoUs with six countries is prepared, namely: Qatar, Greece, Kuwait and Jordan, Japan, Brunei Darussalam, and Morocco.

The simplicity of employment opportunities in the country, cheap and easy delivery processes, low levels of education and skills, low salaries in their own country, and the absence of information to villages about working abroad are cited as the causes of the migration of our citizens' migration abroad as a legal undocumented immigrant worker.

\footnotetext{
15 Ali Ismail Shaleh and Raihana Nasution, "Perlindungan Hukum Tenaga Kerja Indonesia Di Luar Negeri," Pandecta 5, no. 2 (2020): 211-15, https://doi.org/10.15294/pandecta.v5i2.2307.

${ }^{16}$ I Gde Anrizmadha and I Made Sarjana, "Keabsahan Persyaratan Agama Tertentu Dalam Proses Rekrutmen Tenaga Kerja Di Indonesia," Kertha Semaya: Journal Ilmu Hukum 8, no. 5 (2020): 678-88, https://ojs.unud.ac.id/index.php/kerthasemaya/article/view/58482.

17 Adharinalti, "Perlindungan Terhadap Tenaga Kerja Indonesia Irregular Di Luar Negeri," Jurnal Rechts Vinding: Media Pembinaan Hukum Nasional 1, $\quad$ no. 1 (2012): 157-73, https://rechtsvinding.bphn.go.id/artikel/ART 9 JRV VOL 1 NO 1 PROTECT.pdf.
} 


\section{Conclusion}

Meanwhile, the institutional arrangement of legal protection for workers aims to guarantee equality in obtaining opportunities and freedom from discriminatory treatment, including freedom from different treatment based on one's religion. It is necessary to ratify it as a form of the Government's seriousness in efforts to protect the rights of Indonesian workers abroad as rights that can accommodate the mandate of the 1945 Constitution of the Republic of Indonesia.

The existence of this regulation is still not able to realize a complete protection system for a person/worker who wants to get a job. This is because there are still forms of discrimination carried out by employers by determining various requirements, which are migrant workers regardless of their legal status and regulating the rights that apply to migrant workers and fundamental freedoms for migrant workers. One of which is the requirement regarding certain religions during the recruitment process for workers. Following the role and position of the workforce, it is necessary to develop manpower to improve the quality of the workforce and their participation in development and to increase the protection of workers.

An international convention that comprehensively regulates the relationship between migration of people and human rights. Looking for ways to develop the relationship between these units, either through cooperation or competition. The suggestions of this research that are useful for immigrant workers to provide is the hope of the Government to be more assertive in addressing the outstanding issues regarding abuse and discrimination of immigrant workers considering that in Indonesia related to race is very vulnerable causing conflict. Hence, it is necessary to take decisive action to avoid conflict in society due to acts of discrimination. Then it is necessary to develop and expand employment opportunities in Indonesia.

Many people still need work, but limited employment opportunities will create competition in society for citizens themselves who need fields and increased competence. Simultaneously, diplomacy between countries can solve problems that are highly regarded as complexities with different legal systems. Simply put, there needs to be an affirmation of international regulations on the International Convention on the Protection of The Rights of All Migrant Workers and Members of Their Families.

\section{Acknowledgments}

The authors would like to thank the Government and previous researchers for contributing ideas and opportunities for current research, but there are few crucial inputs for the Government of Indonesia. The need to strengthen bipartite negotiations between trade unions and employers in negotiating wages, working conditions, and working conditions, as follow: (1) Expanding cooperation both with destination countries as well as with local governments and community elements to improve the protection of Migrant workers, (2) Increase efforts to harmonize standardization and competency certification through crosssectoral collaboration. Improving supervision related to the government structure on immigrant employment permits in the regions; Increasing the understanding of migrant workers on the principles of human rights to equip migrant workers with sufficient knowledge of their rights while working abroad; Expanding cooperation both with destination countries and with local governments and community elements to improve worker protection and the need to facilitate immigrant work legality permits. Important input is also for migrant workers to pay attention to legality permits and competencies that need to be improved as well as physical and spiritual readiness so that ethical behavior can be maintained. Important input for further researchers to improve the analysis of the Article that the author is researching 


\section{REFERENCES}

Adharinalti. "Perlindungan Terhadap Tenaga Kerja Indonesia Irregular Di Luar Negeri." Jurnal Rechts Vinding: Media Pembinaan Hukum Nasional 1, no. 1 (2012): 157-73. https://rechtsvinding.bphn.go.id/artikel/ART 9 JRV VOL 1 NO 1 PROTECT.pdf.

Anrizmadha, I Gde, and I Made Sarjana. "Keabsahan Persyaratan Agama Tertentu Dalam Proses Rekrutmen Tenaga Kerja Di Indonesia." Kertha Semaya : Journal Ilmu Hukum 8, no. 5 (2020): 678-88. https://ojs.unud.ac.id/index.php/kerthasemaya/article/view/58482.

Graeme, Hugo and W. R. Bohning. Providing Information to Outgoing Indonesian Migrant Workers. Manila: International Labour Office, 2000.

Hanifah, Ida. "Peluang Tenaga Kerja Asing Untuk Bekerja Di Indonesia Berdasarkan Rancangan Undang-Undang Cipta Kerja." De Lega Lata: Jurnal Ilmu Hukumm 6, no. 1 (2020): 158-73. https://doi.org/10.30596/delegalata.v6i1.5536.

Indriani, Maulida. "Peran Tenaga Kerja Indonesia Dalam Pembangunan Ekonomi Nasional." Gema Keadilan 3, no. 1 (2016): 74-85. https://doi.org/10.3592/2.

Koesrianti. "Perlindungan Hukum Pekerja Migran Penata Laksana Rumah Tangga (PLRT) Di Luar Negeri Oleh Negara Ditinjau Dari Konsep Tanggung Jawab Negara." Yustisia Jurnal Hukum 4, no. 2 (2015): 245-68. https://doi.org/10.20961/yustisia.v4i2.8642.

Koh, David. "Migrant Workers and COVID-19." Occupational \& Environmental Medicine 77, no. 9 (2020): 634. https://doi.org/10.1136/oemed-2020-106626.

KSBSI. "Dilema Diskriminasi Buruh Perempuan Industri Garmen Ditengah Pandemi." www.ksbsi.org, 2020. https://www.ksbsi.org/home/read/1327/Dilema-DiskriminasiBuruh-Perempuan-Industri-Garmen-Ditengah-Pandemi.

Marpi, Yapiter. "The Criticism of Social Justice in Economic Gap." Insignia: Journal of International Relations 2 (2021): 23-31.

Moyce, Sally C., and Marc Schenker. "Migrant Workers and Their Occupational Health and Safety." Annual Review of Public Health 39, no. 1 (2017): 13-17. https://doi.org/10.1146/annurev-publhealth-040617-013714.

Muhammad, Abdulkadir. Hukum Dan Penelitian Hukum. Bandung: PT.Citra Aditya Bakti, 2014.

Neef, Andreas. "Legal and Social Protection for Migrant Farm Workers: Lessons from COVID-19." Agriculture and Human Values 37 (2020): 641. https://doi.org/10.1007/s10460-020-10086-w.

Nuraeny, Henny. "Trafficking of Migrant Workers in Indonesia: A Legal Enforcement and Economic Perspective of Prevention and Protection Efforts." European Research Studies Journal 20, no. 4B (2017): 17. https://doi.org/10.35808/ersj/871.

Rosalina, H.N., and L. T. Setyawanta. "Perlindungan Hukum Terhadap Pekerja Migran Sektor Informal Dalam Perspektif Teori Bekerjanya Hukum Di Masyarakat.” Jurnal Pembangunan Hukum Indonesia 2, no. 2 (2020): 174-87. https://doi.org/10.14710/jphi.v2i2.174-187. 
Shaleh, Ali Ismail, and Raihana Nasution. "Perlindungan Hukum Tenaga Kerja Indonesia Di Luar Negeri." Pandecta 5, no. 2 (2020): 211-15. https://doi.org/10.15294/pandecta.v5i2.2307.

- "Perlindungan Hukum Tenaga Kerja Migran Indonesia Di Arab Saudi Sebagai Negara Non Internasional Convention on the Protection of the Rights of All Migrant Wokers and Members of Their Families." Jurnal Yustisiabel 4, no. 1 (2020): 27-36. https://doi.org/10.32529/yustisiabel.v4i1.481.

Sweileh, Waleed M. "Global Output of Research on the Health of International Migrant Workers from 2000 to 2017." Globalization and Health 14, no. 105 (2018): 2. https://doi.org/10.1186/s12992-018-0419-9. 
